\title{
CALibration OF Nitrogen FerTiLizer for Quality Protein Maize (Zea mays L.) BASED ON IN-SEASON ESTIMATED YIIELD USING A HANDHELd NDVI SENSOR IN THE CENTRAL RIFT VALLEY OF ETHIOPIA
}

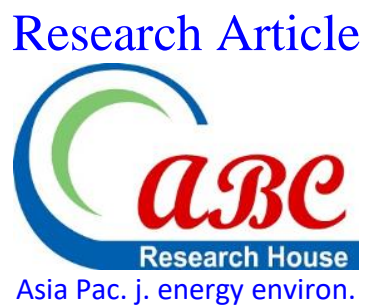

Addis Tadesse $^{1 *}$, Hae Koo Kim², Adugna Debela ${ }^{3}$

${ }^{1}$ Department of Agronomy and Soil Fertility, Jimma Agricultural Research Center, Ethiopian Institute of Agricultural Research, P.O.Box 192, Jimma, ETHIOPIA

${ }^{2}$ International Center for Wheat and Maize Improvement (CIMMYT) Ethiopia, P.O.Box 1024, Addis Ababa, ETHIOPIA

${ }^{3}$ Department of Horticulture and Plant Science, Jimma University College of Agriculture and Veterinary Medicine, Jimma University, P.O.Box 307, Jimma, ETHIOPIA

*Email for Correspondence: addytad@gmail.com

\begin{abstract}
Maize is one of a highly valued crop in the national diet of Ethiopians especially in southern and southeastern regions of the country; it is produces across various agro-ecologies of the country. However, its productivity is constrained by blanket application of mineral nutrients, in particular, nitrogen $(\mathrm{N})$. In this study, we aimed to test site-specific nutrient management supported by precision agriculture tools can provide extension agents and farmers better ways to manage nitrogen, to increase net benefit and reduce environmental pollution. The drastic increase in $\mathrm{N}$ fertilizer cost, environmental pollution and increased public scrutiny have encouraged development and implementation of improved $\mathrm{N}$ management practices. In this context, on-farm and on-station experiment was conducted during 2014 main cropping season in the central rift valley of Ethiopia. The objective of the study was calibrating $\mathrm{N}$ fertilizer rate using the handheld NDVI sensor for efficient management of $\mathrm{N}$ to optimize grain productivity. The trials were layout in a randomized complete block design with seven levels of $\mathrm{N}$ fertilizer with phosphorus applied uniformly. The study evaluated the relationship between grain yield and NDVI using the handheld Green seeker sensor. The result shows that a strong nonlinear relationship $(\mathrm{R} 2=0.79)$ were exist between NDVI values and harvest grain yield. In similarly fashion positive exponential relationship ( $2=0.71)$ between INSEY and grain yield during vegetative growth stage six (V6) at both locations. Overall this study shows that the handheld NDVI sensor can be an indicator to better manage $\mathrm{N}$ fertilizer application.
\end{abstract}

Key words

Growing degree day (GDD), In-season Estimated Yield (INSEY), Normalized Difference Vegetative Index (NDVI), Precision agriculture (PA)

Source of Support: None, Conflict of Interest: None Declared

This article is is licensed under a Creative Commons Attribution-NonCommercial 4.0 International License.

Attribution-NonCommercial (CC BY-NC) license lets others remix, tweak, and build upon work non-commercially, and although the new works must also acknowledge \& be non-commercial.

\section{INTRODUCTION}

Maize (Zea mays L.) is one of the most valuable cereal crops used in the human nutrition in various parts of the globe and it is a vital feed source for livestock. In addition to food and feed consumption, maize has extensive range of industrial applications as well; from food processing to manufacturing of ethanol. Global maize production exceeds 600 metric tons (Donald and Nicol, 2005). Maize is one of the most important cereal crop cultivated in Ethiopia (CIMMYT, 2012). Maize followed teffin area coverage whereas first in total production. According to a 2013/14 survey, meher (productive) season post-harvest crop production cover total land areas of about 12,407,473 
hectares were covered by grain crops. Out of the total grain crop areas, $79 \%(9,848,746$ ha) was under cereals. Of this maize covered $16 \%$ (about 1,994,814 ha), and 18\% $(44,186,225)$ quintals of grain yields (CSA, 2014).

Despite the large area under maize cultivation, its national average yield of is about $3.2 \mathrm{t} / \mathrm{ha}$ (CSA, 2014). This yield is by far below even the world's average yield which is about 5.21t/ha (FAO, 2011). The yield gap is attributed to a number of factors like frequent occurrence of drought, declining of soil fertility, poor agronomic practice, limited use of input, poor seed quality, disease, and others (CIMMYT, 2004).

Nutrient deficiency is one of the major problems constraining the development of an economically effective agriculture (Fageria and Baligar, 2005). It is projected that some 30 to $50 \%$ of the increase in world food production since the 1950s is attributable to fertilizer use (Higgs et al., 2002) Nevertheless, many farmers refrain from using fertilizer due to escalating costs, uncertainty about the economic returns to fertilizing food crops and more often, lack of knowledge as to which kinds and rates of fertilizers are suitable (Hopkins et al., 2008).

The supply of food for human being and feed for animals more limited over $\mathrm{N}$ than any other element, since large amount of $\mathrm{N}$ is lost through denitrification, leaching, volatilization and removal by crops (Acquaah, 2002). The maximum $\mathrm{N}$ uptake by maize occurs during the month prior to tasselling and silking (Hammons, 2009). Since yield is likely to be low under $\mathrm{N}$ stress during silking, coincidence of $\mathrm{N}$ availability in soil solution, and plant uptake demands are crucial to unlocking the potential of modern hybrids. Indeed, poor kernel formation increased abortion and ultimately low grain yield under $\mathrm{N}$ stress have been reported widely (Andrade et al., 2000). In addition to releasing QPM varieties it would be very important to have site specific nutrient management packages to increase production and productivity of QPM for the benefit of producer in Ethiopia in terms of nutrition, economic and reduce environmental protection. Site-specific nutrient management aims at 'doing the right thing, at the right place, at the right time', and when used in combination with information technologies it defines 'precision agriculture' (Bongiovanni and Deboer, 2004). Precision agriculture is associated with large-scale commercial farmers using satellite and sensor-based technologies and is commonly perceived as remote from African smallholder agriculture. However, in the early-2000s, the company Trimble started manufacturing a hand-held Normalized Difference Vegetation Index (NDVI) sensor, a real step towards popularizing precision agriculture, regardless of farm-scale.

NDVI has correlated too many variables such as crop Nitrogen deficiency, final grain yield, and long-term water stress. The use of hand-held NDVI sensor could bring precision agriculture to African smallholders, improving crop productivity, increasing returns on $\mathrm{N}$ fertilizer and reducing the risk of environmental pollution. The relationship between NDVI and grain yield was further improved when NDVI was normalized by dividing it by the number of days from planting to sensing where the growing degree days $\left(\mathrm{GDD}=\left[(\mathrm{Tmin}+\mathrm{Tmax}) / 2-10^{\circ} \mathrm{C}\right],(\mathrm{T}-\mathrm{min}\right.$ and $\mathrm{T}-\mathrm{max}$ recorded from daily data) greater than zero (Lukinaet al., 2001). Positive GDD are days where growth is possible and in-season estimated yield (INSEY), the insignia given to NDVI normalized by ambient temperature, measures biomass produced per day of positive growth (Raunet al., 2001).

Farmers in the utmost part of Ethiopian only use basal application of N mostly once in a blanket recommendation, which result in loss of $\mathrm{N}$ through leaching and volatilization, reduced $\mathrm{N}$ use efficiency and yield. Hence, much of the work associated with making fertilizer recommendations has not considered the potential focusing in-season prediction of potential grain yield use of NDVI sensors to upturn economic as well as environmental health. However, appropriate rates and time of $\mathrm{N}$ fertilizer application have not been devised to improve fertilizer use efficiency and productivity of maize in the study area. To this point, $\mathrm{MH} 138 \mathrm{Q}$ variety is among the recently released QPM maize variety since, 2012. There is no specified $\mathrm{N}$ fertilizer recommendation for the cultivarin the study area rather blanket recommendation used at the national level. Therefore, the study was conducted with the objective of calibrating $\mathrm{N}$ fertilizer based on in-season estimated yield using a handheld NDVI sensor for efficient management of $\mathrm{N}$ for a QPM variety.

\section{Materials AND Methods}

\section{Description of study area}

The experiment was conducted on two locations of central rift valley of Ethiopia, on station (Melkassa Agricultural Research Center) and on farm in Oromia Administrative Region, Adami Tulu Jidokombolchawereda Gerbi Wedina Boremokebele, South Eastern part of Ethiopia during 2014 main cropping season. The difference locations were aimed to provide site-specific recommendation for $\mathrm{N}$ application. Thefarmer site is located about $5 \mathrm{~km}$ away to Southern part from Ziway town. The geographical coordinate of the study site were at about $7^{\circ} 72^{\prime} \mathrm{N}$ Latitude and $38^{\circ} 37^{\prime} \mathrm{E}$ longitude, and an elevation of 1600 meter above sea level (m.a.s.l). The area receives a mean annual maximum rainfall of $750 \mathrm{~mm}$ and minimum rainfall of $546 \mathrm{~mm}$, mean annual maximum temperature of $28.5^{\circ} \mathrm{C}$ and mean annual minimum temperature of $12.6^{\circ} \mathrm{C}$ (Getachewet al., 2012). The area is classified as sub moist semi-arid and arid agro ecology, and the major soil type of the area is loam with an alkaline $\mathrm{pH}$. Whereas Melkassa 
Agricultural Research Center (MARC) was established in 1969.The Center is geographically located at a latitude of $8^{\circ}$ $24^{\prime}$ Longitude of $39^{\circ} 21^{\prime}$ East and an altitude of 1,550 meters. It is situated at about $107 \mathrm{~km}$ from Addis Ababa and 17 $\mathrm{km}$ from Adama on the way to Asella. Loam and clay loam soil textures are the principal soils of the area (MARC, 2012).

\section{Experimental Materials}

Plant Material: MH138Q, which is a three-way cross QPM hybrid released by Melkasa Agricultural Research Center in 2012 (EIAR, 2014), was used for the study; it is well adapted to drought stressed mid-altitude areas of Ethiopia (1000 -1800 m.a.s.1), such as Welenchiti, Meki, Ziway, Adami Tulu and rain-fall of 500-1000 mm. It needs 140 days to maturity, having a white kernel, light yellow pollen color, semi-dent grain texture with straight kernel row arrangement and resistance to rust and blight. It performs better if planted during late May to mid-June. It has yielded potential ranges from 7-8 $\mathrm{t} \mathrm{ha}^{-1}$ yields at research field and 5.5-6.5t ha ${ }^{-1}$ at farmers field (MARC, 2013).

Fertilizers: We use $\mathrm{N}$ fertilizer in the form of urea $(46 \% \mathrm{~N})$ and DAP for the study. N- Fertilizer applied at different rates in a split application, while phosphorus-fertilizer was applied uniformly to all plots of each treatment at the time of planting.

Description of the hand-held NDVI Sensor (Green Seeker): The handheld Green-Seeker crop sensor is simple to use measurement device that can be used to assess the health or vigor of a crop. Readings taken by the sensor can be used to make non-subjective decisions regarding the amount of fertilizer to be applied to a crop, resulting in a more efficient use of fertilizer. Upon pulling the trigger, the sensor turns on, emits brief bursts of red and infrared light, and then measures the amount of each type of light that is reflected back at the sensor. The sensor continues to sample the scanned area as long as the trigger remains engaged, the strength of the detected light is a direct indicator of the plant's vigor, and the sensor displays the measured value in terms of an NDVI reading on its LCD screen (Trimble, 2012).

NDVI is a commonly used measurement of crop health in agricultural applications. NDVI is Calculated as NDVI= (NIR reflected - Red reflected) / (NIR reflected +Red reflected), where Red and NIR stand for the spectral reflectance measurements acquired in the red and near-infrared regions, respectively. NDVI readings can range from 0.00 to 0.99 ; the higher the reading, the healthier the plant, Healthier crop canopy will absorb more red and reflect more near-infrared light, and consequently has a higher NDVI value (Lanet al, 2009). Linear and nonlinear regression models were used to determine the relationships present between grain yield and NDVI using Procedures in SAS.

\section{Experimental Design and Treatments}

Treatments consisted of seven rates of $\mathrm{N}\left(0,10,25,50,75,100\right.$ and $\left.125 \mathrm{~kg} \mathrm{~N}^{-1}\right)$ in a split application, half during planting and the remaining half after emergence at vegetative stage.The size of each plot was $4.5 \mathrm{~m} \times 5.1 \mathrm{~m}(22.95$ $\mathrm{m}^{2}$ ), consisting of six rows and the distance between adjacent plots and blocks kept at $1.0 \mathrm{~m}$ and $1.5 \mathrm{~m}$ apart, respectively. Seeds were sown with inter-rows spacing of $75 \mathrm{~cm}$ apart and intra-row spacing of $25 \mathrm{~cm}$, three to two seeds per hill were sown to ensure emergence and a good stand of the crop. However, to obtain the required plant density the seedlings were thinned to one plant per hill two weeks after emergence. The net plot area was $2.25 \mathrm{~m} x$ $5.1 \mathrm{~m}\left(11.47 \mathrm{~m}^{2}\right)$. Consequently, the experiment was laid out as a randomized complete block design (RCBD) replicated three times.

\section{Experimental procedures}

Fertilizer application and field activities: Planting was done on June 2014 by placing two seeds per hill in hand made furrows and tinning to one seedling to inter-row and intra-row spacing of $75 \mathrm{~cm}$ and $25 \mathrm{~cm}$, respectively. Phosphate fertilizers in the form of triple super phosphate (TSP) were equally applied to all plots manually at the time of planting. For the $\mathrm{N}$ fertilizer application, urea was applied in two split at the specified rates by banding at planting approximately $2-3 \mathrm{~cm}$ distance from the seed (plant) and immediately covered with soil and by top dressing during the growth of the plants. All field activities were carried out following standard production practices.

Weeds were controlled manually either pulling with hand or using a hoe during cultivation. Stand count at emergence to see the uniformity of the plant stand, NDVI measurement using pocket handheld sensor was taken from the central four rows of net plot area at vegetative stage four (V4) and vegetative stage six (V6), in line with this other growth parameters, stand count, number of fully expanded leaf, plant Height, leaf length, and width continuously with in fifteen days interval were recorded Finally, maize plants in the central four row that had net plot area $(11.47 \mathrm{~m} 2)$ were harvested November 2014. 


\section{RESULTS AND DISCUSSION}

\section{Normalized Difference Vegetative Index (NDVI)}

\section{The NDVI versus $\mathrm{N}$-fertilizer rate}

Normalized difference vegetative index with hand-held sensor at both stages $\left(\mathrm{V}_{4} \& \mathrm{~V}_{6}\right)$ was significantly $(\mathrm{P}<0.01)$ affected by rate of applied N-fertilizer. The highest NDVI value was recorded from the higher N-fertilizer the rate $75 \mathrm{~kg} \mathrm{~N} \mathrm{ha}{ }^{-1}$, and it shows a consistent increase in NDVI value as $\mathrm{N}$ rate increased from the control treatment up to $75 \mathrm{kgN} / \mathrm{ha}$. The nonlinear regression model (Fig.1) also indicates the equation predicted NDVI with rate of fertilizer relationship define with $\mathrm{R}^{2}=93 \%$ and $\mathrm{R} 2=98 \%$ at both locations during vegetative stage six. As the N-level rise NDVI readings from the NDVI sensor become higher under MARC condition at $V_{4} \& V_{6}$, but the increment is not uniform between these two stage, clear difference was observed at $\mathrm{V}_{6}$ stage of maize plant. This difference could be the result of higher nutrient demand as growth continues in particular after V4, so that a clear difference is observed among treatments.

The result of NDVI shows that readings become greater while growth continues after $\mathrm{V}_{4}$, but it was small at the binging. However, in maize plant grow up and there is space between the plants. This space and failure of the canopy to be completely closed probably results in the poorer correlation at young vegetative stages $\mathrm{V}_{4}$. Correlation was possible low due to the initial growth stage and lack of early $\mathrm{N}$ stress. Starting at $\mathrm{V}_{5}$ and later vegetative stages, the correlation and model improved most likely due to a more similar canopy. These results in agreement with the finding of Raunet al. (2001) reported that the greatest variation occurred at $\mathrm{V}_{6}$, and as the canopy closed.

The NDVI is successful in predicting photosynthetic activity because this vegetation index includes both near infrared and red light. Plant photosynthetic activity is determined by chlorophyll content and activity. Many literatures stated increment in $\mathrm{N}$ level enhance Spectral vegetation indices such as the NDVI which have been correlation, shown to be useful for indirectly obtaining information such as photosynthetic efficiency, productivity potential, and potential yield (Baez-Gonzalez et al.,2002).
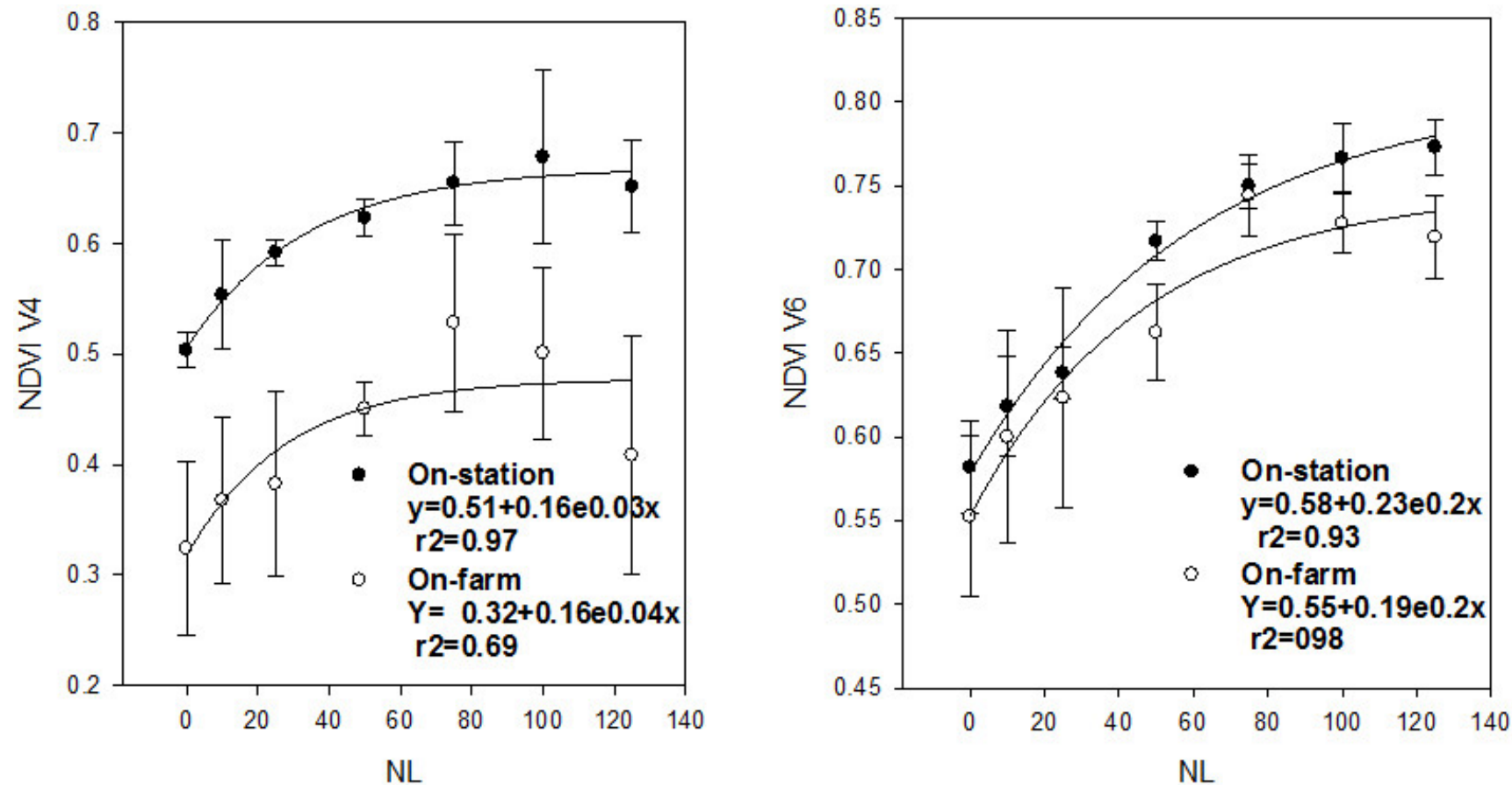

Figure 1: The Nonlinear relationship between applied N Level and Measured NDVI values at both locations, Main Cropping Season 2014.

\section{Relationship between NDVI and grain yield}

Regression analysis indicates a sturdy $(\mathrm{P}<0.01)$ relationship between NDVI and grain yield at both locations. The highest value recorded on both parameters, at fertilizer rate of $75 \mathrm{kgN} / \mathrm{ha}$, whereas lowest values recorded at the control treatment at both sites. The regression model fitted with the equation $Y=2.12 e^{1.96 x}$ and $Y=0.14 e^{5.18 x}$ through $V_{4}$ and $\mathrm{V}_{6}$ at both locations (fig.2). 
Likewise, the correlation analysis (Table.1) indicates that there exist strong relationships between the NDVI and harvested Grain yield as well as the rate of $\mathrm{N}$ fertilizer at both locations. These results confirm that hand held NDVI sensor the right indicator of crop health, unstressed and which can provide maximum yield. On the other side thus shows the hand-held sensor is one of the best instruments in precision agriculture to manage nutrients for economic return as well as to reduce environmental pollution as result of poor $\mathrm{N}$ fertilizer management.

According to Moges, (2004) similar result was found by Lukina, (2001) NDVI readings taken at these same stages were positively correlated with final grain yield. These results disagreement with Fernando (2008) who reported that linear relationships between variation in relative grain yield and relative values for two sensor-determined vegetation indices.
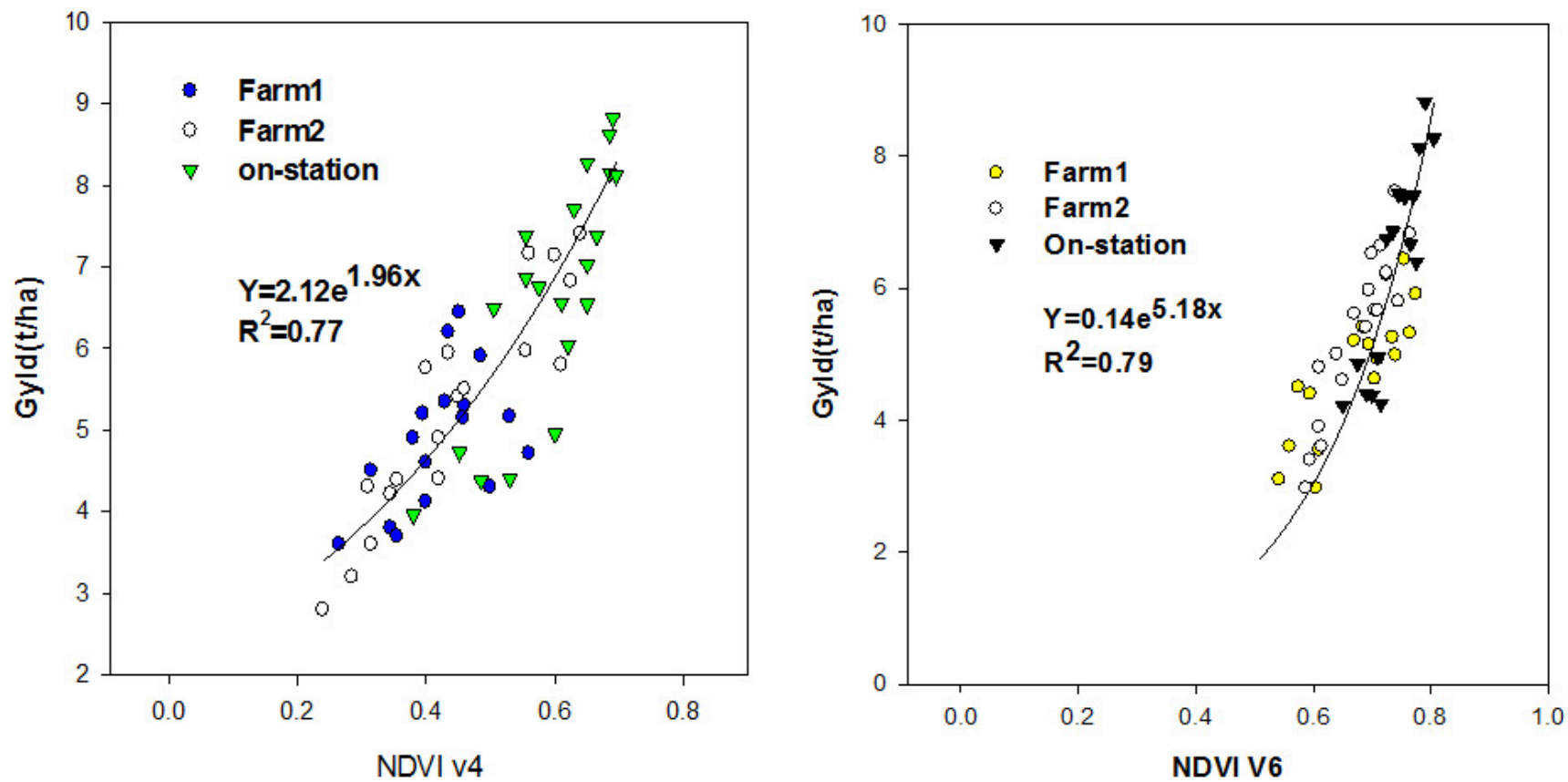

Figure 2: Graph of scattered plot shows the nonlinear regression model between NDVI and grain yield of maize on-farm and onstation, 2014, main cropping season.

\section{Use of INSEY as a predictor of grain yield at harvest}

\section{Relationship between INSEY and N Fertilization}

The graphs of regression analysis indicate a strong relationship between the in-season yield estimate and applied treatment in farm condition $R^{2}=0.76$ at $V_{4}$ and $R^{2}=0.93$ at $V_{6}$ respectively, this designates that a great deal of the variations in $\mathrm{N}$ Fertilizer among individuals is explained, through an exponential maximumrelationship differences in INSEY at both stage of growth (fig.3).

The INSEY increases as the fertilizer rate increase steadily from the control towards $100 \mathrm{Kg} \mathrm{N} \mathrm{ha}^{-1}$ at Adami Tulu, this is due to that $\mathrm{N}$ fertilizer have great role in plant growth and development, and also in the development of chlorophyll content of the leaf, Since $\mathrm{N}$ gives the green color to the leaf appearance thus contributes to the increment in NDVI reading values finally to achieve higher in-season yield estimate.Likewise, at MARC the regression and correlation analysis shows that there exist a strong relationship $\left(R^{2}=0.94 \& R^{2}=0.97\right)$ at vegetative growth stages $V_{4} \&$ $\mathrm{V}_{6}$ correspondingly. In addition to this the result of analysis of variance indicated that there exists a significant difference between the INSEY with application of N-fertilizer rate. The higher INSEY value was recorded from the application of $100 \mathrm{~kg} \mathrm{~N} \mathrm{ha}^{-1}$ at vegetative stage four. However, growth continues at $\mathrm{V}_{6}$ the higher INSEY values were recorded from the addition of $100 \mathrm{~kg} \mathrm{~N} \mathrm{ha}^{-1}$.

This is because of canopy structure development, as the growth continues the nutrient demand of the plant become increased up to some level of growth and also the canopy closure at each vegetative stage is different, hence nutrient use efficiency, conversion factor and photosynthesis rate become differ, this results the difference in the NDVI readings and finally to have varied INSEY. However in both growth stages the lowest value was recorded from the control treatment. This result in agreement with Lukinaet al.(2001) proposed procedure prescribes increased $\mathrm{N}$ rates in areas of the field with high yield potential as indicated by INSEY and reduced N fertilizer in areas of the experimental plot with lower yield potential. 

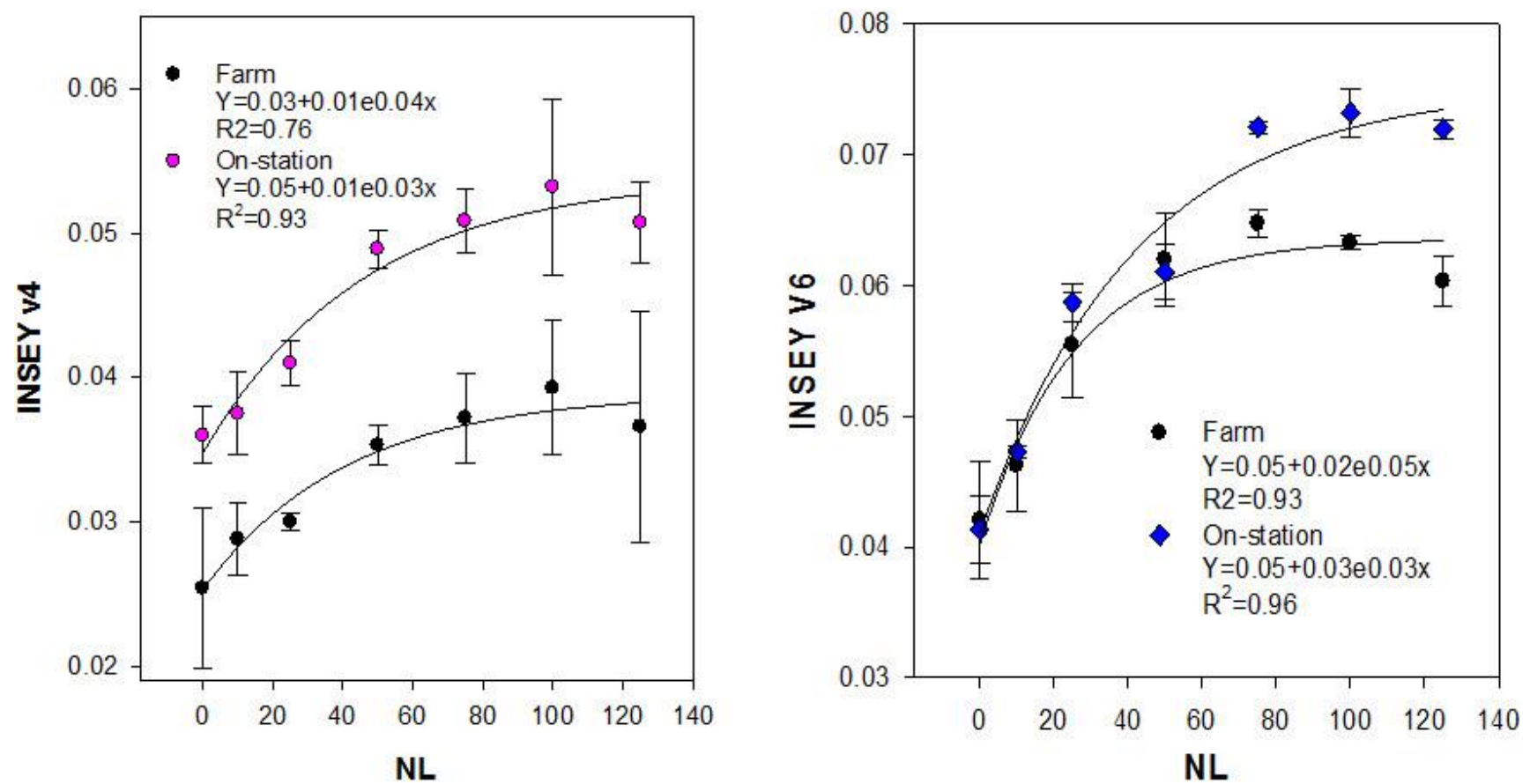

Figure 3: Nonlinear Regression Model between N-Level and INSEY at both locations, during 2014 Main Cropping Season, at both Vegetative Stage Four and Six.

\section{Relationship between INSEY and grain yield}

The result of analysis of variance shows that a significant difference among INSEY values was observed in response to applied treatments $(\mathrm{P}<0.01)$. Also the regression and correlation analysis indicated that there exist a strong $\left(R^{2}=0.70\right)$ relationship between the estimated yield and the harvested (measured) grain yield during vegetative growth stage $\mathrm{V}_{6}$, in both locations (fig.4).

Measured grain yield was increased consistently up to $100 \mathrm{~kg} \mathrm{~N} \mathrm{ha}^{-1} \mathrm{~N}$ fertilizer were applied in a similar pattern the INSEY increase, a gradually result of both parameters decline. On the other side, the smallest result of both, grain yield, and INSEY was recorded from the control treatments' at both vegetative stages $\left(V_{4} \& V_{6}\right)$ of growth. However, there is a non-significant difference among replication especially at Vegetative stage six $\left(\mathrm{V}_{6}\right)$, this might be due to the canopy closure as growth continues, and create higher in the NDVI sensor reading values.

Similar result is also reported by Vinaet al. (2004) due to canopy closure influence on the sensor field of view, the later NDVI readings were unable to distinguish variation, similar to research findings for other remote sensing techniques measuring NDVI. A similar report, a strong relationship existed between wheat grain yield and INSEY, with a coefficient of determination of $83 \%$ (Raunet al., 2001).

$$
\begin{aligned}
& \text { i.e. } I N S E Y=\frac{N D V I}{G D D} \\
& \text { Where: } \quad \begin{array}{l}
G D D=\frac{(T \max +T \min )}{2}-b T \quad \text { (Ruan et.al, .2001) } \\
\text { Where bT= Base temperature of maize. }
\end{array}
\end{aligned}
$$




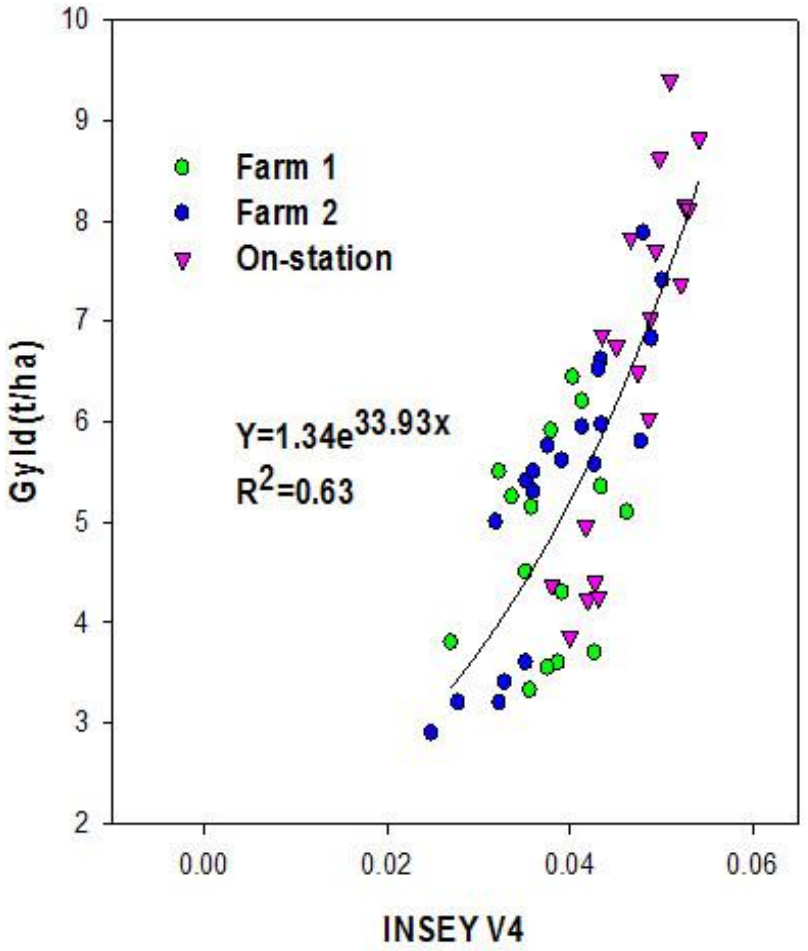

(a)

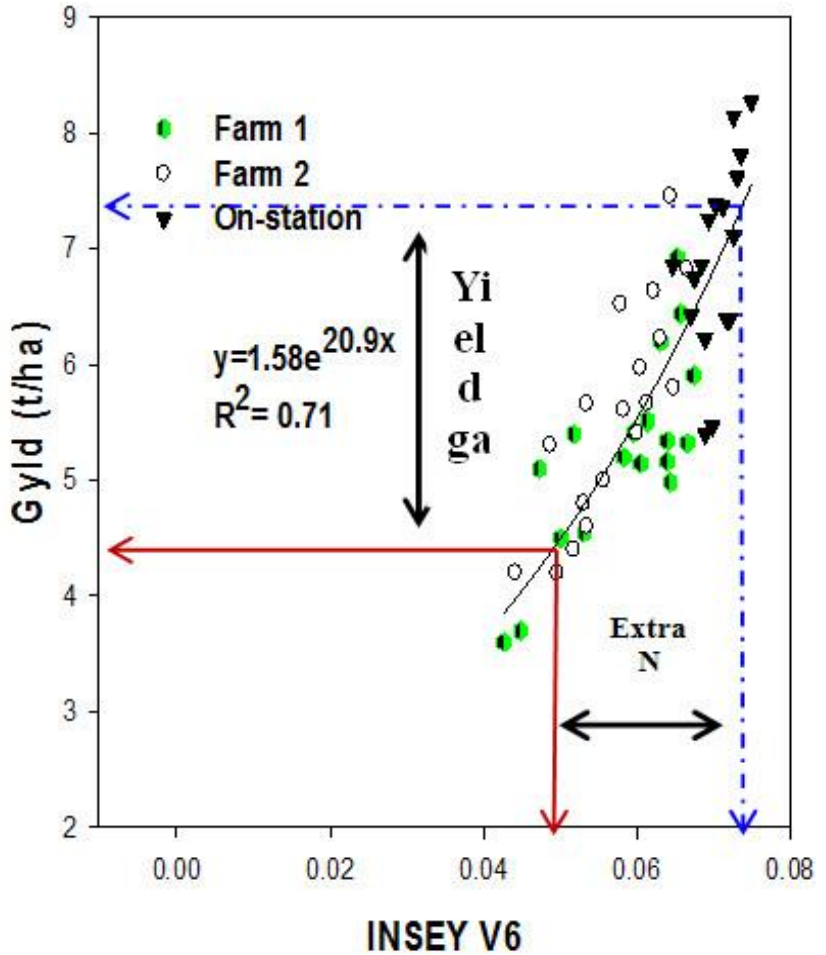

(b)

Figure 4: Exponential regression model between In-season estimated yield (INSEY) and measured grain yield, at V6 growth stage in both locations, main cropping season.(Where fig. $4 \mathrm{~b}$ refers the yield gap due to extra $\mathrm{N}$ fertilizer required achieving potential yield.)

Table 1: Correlation Coefficient between mean NDVI, INSEY Grown under different N Rate of the application at both locations during 2014 Main Cropping Season

\begin{tabular}{lccccccc}
\hline X & NL & Gyld & NDVI V4 & INSEY V4 & NDVI V6 & INSEY V6 & SN \\
\hline NL & 1 & $0.706^{*}$ & $0.798^{* *}$ & $0.763^{* *}$ & $0.807^{* *}$ & $0.741^{* *}$ & $0.681^{* *}$ \\
Gyld & & 1 & $0.756^{* *}$ & $0.736^{*}$ & $0.722^{*}$ & $0.784^{* *}$ & $0.725^{*}$ \\
NDVI V4 & & & 1 & $0.981^{* *}$ & $0.747^{* *}$ & $0.653^{*}$ & $0.470^{*}$ \\
INSEY V4 & & & & 1 & $0.731^{*}$ & $0.642^{*}$ & $0.447^{*}$ \\
NDVI V6 & & & & & 1 & $0.803^{*}$ & $0.599^{*}$ \\
INSEY V6 & & & & & & 1 & $0.391 \mathrm{~ns}$ \\
SN & & & & & & & 1
\end{tabular}

Where, NL=nitrogen level, GYLD=grain yield, NDVI $\mathrm{V}_{4}=$ normalized vegetative index at vegetative stage four, INSEY $\mathrm{V}_{4}=$ in season yield estimate at vegetative stage four, NDVI $\mathrm{V}_{6}=$ normalized difference vegetative index at stage six, INSEY $\mathrm{V}_{6}=$ in season estimated yield at vegetative stage six, NS, ${ }^{*}, * *$ and ${ }^{* *}=$ non-significant, significantly different at $5 \%, 1 \%$, and $0.1 \%$, respectively.

\section{CONCLUSIONS}

Nutrient management conventionally focused on enhancing the economic returns from nutrients used to produce a crop. Recently, nutrient management also has started to include ways to reduce the negative impact of chemical nutrients on the environment. Sustaining soil and soil fertility in intensive cropping systems for higher yields and better quality can be achieved through better management of fertilizer application. Thus, information on fertility status of soils and crop response to different soil fertility management is very crucial to come up with profitable and sustainable crop production.

According to this study, determining the $\mathrm{N}$ status of the crop with in-season estimated yield (INSEY) using a handheld NDVI sensor also is one of the effective ways for $\mathrm{N}$ management in Ethiopian smallholder farms. This work reports on an alternative method of determining fertilizer $\mathrm{N}$ rates using estimates of early-season plant $\mathrm{N}$ uptake and potential yield determined from in-season spectral measurements and provide site-specific recommendation. Significant differences were observed on measured NDVI at both V4 and V6 growth stages. Overall, there was a strong 
relationship and significant correlation between NDVI and grain yield up to $100 \mathrm{~kg} \mathrm{~N}$ ha-1 at both locations even though on-farm become saturate early as compared to on-station. Regression and correlation analysis of harvested grain Yield shows a strong positive relationship (R2=0.87 at V4 \& $\mathrm{R} 2=0.96$ at V6) with NDVI. Similarly, there was a strong relationship between grain yield $(\mathrm{R} 2=0.71)$ and INSEY. This study demonstrates that the NDVI sensor can be a very good indicator of $\mathrm{N}$ status of maize crop at early vegetative stage for $\mathrm{N}$ management in the central rift valley context. Based on the result of this study, to fill the yield gap appropriate management of $\mathrm{N}$ is mandatory thus, we could conclude that application of $\mathrm{N}$ fertilizer at the rate $75 \mathrm{~kg} \mathrm{~N}$ ha- 1 to achieve best performance of QPM variety MH138Q in the study area. However, further similar studies are required across various locations using different maize varieties to provide conclusive recommendations and to validate the results.

\section{REFERENCES}

Acquaah, G., 2002. Principles of Crop Production Theory, Techniques, and Technology Prentice Hall of India, Langston University. New Delhi. Agronomy Journal, 91: 357-363.

Andrade, F.H., Ortega, M.E. and Vega, C., 2000.Intercepted Radiation at Flowering and Kernel- Number in Maize, Agronomy Journal, 92: 92-97.

Bill Raun, Randy Taylor, John Solie, Marvin Stone., and Brian Arnall, 2011. Final report, Program to Improve the Adoption Rates and Efficiency of Best Management Practices to Protect Oklahoma Waters from Nonpoint Source Pollution Development and Delivery of the Second Generation Optical Pocket Sensor for Maximizing Nitrogen Use Efficiency in Cereal Production Systems.

Bongiovanni, R., LowenbergDeboer, J., 2004. Precision agriculture and sustainability of Precision Agriculture, Brady, N. C. and. Weil, R. R, 2002. The Nature and Properties of Soils (13th edition). Pearson Education Ltd., USA. 5:359-387.

CIMMYT (International Maize and Wheat Improvement Center), 2004.Second Semi-AnnualProgress Report for the QPM Development Project for the Horn and East Africa. July 1- December 31, 2003.

CSA (Central Statistical Agency), 2013/2014. Agricultural Sample Survey: report on area and production of major crops (private peasant holdings, Meher season). Statistical Bulletin, volume1:.Addis Ababa.

Ethiopian Institute of agricultural research, 2012/13. Ministry of Agriculture, National variety release and quarantine directorate.Addis Ababa,Ethiopia.

Fageria, N.K. and Baligar V. C. 2005.Enhancing nitrogen use efficiency in crop plants.Advanced Agronomy. 88: 97-185.

FAO (Food and Agriculture organization of the United Nations). 2011. FAOSTAT online database, available at link http://faostat.fao.org/.

Fernando; Shanahan, John; Ferguson, Richard B.; Schepers, James S.; and Gitelson, Anatoly A., 2008.Active Sensor Reflectance Measurements of Corn Nitrogen Status and Yield Potential.Agronomy \& Horticulture Faculty Publications.Paper 117. http://digitalcommons. unl.edu/agronomyfacpub/117.

Getachew S. 2012. Growing Vulnerability; Population Pressure, food insecurity and Environmental Degradation, Central Rift Valley, Ethiopia.Journal of Biodiversity and Environmental Sciences (JBES). Vol 2: P, 33-41.

Hammons, J. L. 2009. Nitrogen and Phosphorus Fertilization of Corn.Virginia Cooperative Extension.Publication 424-027.

Higgs, B., Johnston, A. E., Salter J.L. and Dawson C. J., 2002.Some aspects of achieving phosphorus use in agriculture.Journal of Environmental Quality. 29: 80-87.

Hopkins, B. G., Rosen, C. J., Shuffler A. K and Taysom, T.W. 2008b.Enhanced efficiency fertilizers for improved nutrient management of potato.University of Idaho, Aberdeen.

Lan, H. Zhang, R. Lacey, W.C. Hoffmann and W. Wu. 2009. "Development of an Integrated Sensor and Instrumentation System for Measuring Crop Conditions". Agricultural Engineering International: CIGR Journal. 21: 11-15.

Lukina, E.V., K.W. Freeman, K.J. Wynn, W.E. Thomason, R.W. Mullen, A.R.Klatt, G.V. Johnson, R.L. Elliott, M.L. Stone, J.B. Solie, and W.R. Raun. 2001. Nitrogen fertilization optimization algorithm based on in-season estimates of yield and plant nitrogen uptake.Journal of Plant Nutrition. 24:885-898.

McDonald, AH. Nicol, JM, 2005. Nematode Parasites of Cereals. pp. 131-191.In: Luc, M., Sikora, R.A. and Bridge, J. (Eds). Plant parasitic nematodes in subtropical and tropical agriculture, 2nd edition. Wallingford, UK, CABI Publishing,

Melkassa Agricultural Research Center, 2013. Maize breeding and genetics department office profile.

NuME(nutritious maize for Ethiopia), 2012.Project implementation plan; Revised and submitted by International Maize and Wheat Improvement Center (CIMMYT) unpublished .Addis Ababa, Ethiopia.

Raun, W.R., G.V. Johnson, M.L. Stone, J.B. Sollie, E.V. Lukina, W.E. Thomason and J.S. Schepers. 2001. In-season prediction of potential grain yield in winter wheat using canopy reflectance. Agronomy Journal, 93:131-138.

Raun, W.R., J.B. Solie, G.V. Johnson, M.L. Stone, R.W. Mullen, K.W. Freeman, W.E. Thomason, and E.V. Lukina. 2002. Improving nitrogen use efficiency in cereal grain production with optical sensing and variable rate application. Agronomy Journal, 94:815-820.

Regassa K, 2005. Effects of integrated use of decomposed coffee husk and inorganic N and P fertilizers on yield and yield related parameters of sorghum on Nitisols of Jimma area. MSc Thesis Paper Presented to the School of Graduate Studies, Alemaya University, Ethiopia. 76p.

S. M. Moges, 2004. Evaluation of Green, Red, and Near Infrared Bands for Predicting Winter Wheat Biomass, Nitrogen Uptake, and Final Grain Yield. Journal of Plant Nutrition, 27: 1431-1441,

Trimble Navigation Limited. 2012. Trimble and the Globe \& Triangle logo are trademarks of Trimble Navigation Limited, registered in the United States and other countries. Connected Farm is a trademark of Trimble Navigation Limited. PN 022503-1124-1 (01/14).

Vina, A., A.A. Gitelson, D.C. Rundquist, G. Keydan, B. Leavitt, and J. Schepers. 2004. Monitoring maize (ZeamaysL.) phenology with remote sensing. Agronomy Journal, 96:1139-1147. 